\title{
COMPARISON OF DIFFERENT DEFINITIONS OF THE METABOLIC SYNDROME IN RELATION TO CORONARY ARTERY DISEASE IN HIGH RISK SERBIAN POPULATION
}

\section{AUTHORS}

Veličković I. ${ }^{1}$, Milin-Lazović J. ${ }^{2}$, Nestorović E. ${ }^{3}$, Ćirković A. ${ }^{2}$, Savić M. ${ }^{3}$, Stojković N. ${ }^{1}$, Mašić S. ${ }^{4}$, Milić N. ${ }^{2}$

${ }_{1}^{1}$ Medical College of Professional Studies, Zemun, Belgrade, Serbia

${ }^{2}$ Institute for Medical Statistics and Informatics, Faculty of Medicine University of

Belgrade, Serbia

${ }^{3}$ Clinic for Cardiosurgery, Clinical Center of Serbia

${ }^{4}$ Department for Primary Health Care and Public Health, Faculty of Medicine University of East Sarajevo
CORRESPONDENT

NATAŠA MILIĆ

Institute for Medical Statistics and Informatics, Medical Faculty University of Belgrade, Serbia

$\triangle$ silly_stat@yahoo.com

\section{SUMMARY}

While different definitions for the diagnosis of metabolic syndrome (MetS) have been proposed, their applicability brings confusion about which criteria should be used in clinical practice. This was an observational cross-sectional study conducted during October 2008. in 3 university hospital centers in the north, midst and south of the Serbia. 1715 patients were recruited from outpatient clinical practice and primary health care offices: $37 \%$ males and $63 \%$ females, aged 34-80 years. To evaluate the impact of different criteria in discriminating high risk population for coronary artery disease (CAD) we used NCEP-ATP III, AHA/NHLBI and IDF definitions. 21,7\% (373) from the patients included in the study sustained CAD. The prevalence of MetS in the CAD group was $84,7 \%, 86,1 \%$ and $82,0 \%$, respectively, compared with $58,3 \%, 60,6 \%$ and $61,2 \%$ in the control group $(p<0.0001)$. ROC curves ploted by the probabilities for CAD calculated in the logistic models for each definition (adjusted for age, sex, smoking and educational status) indicated that NCEP-ATP III and NHLBI-AHA definitions had a better predictive accuracy compared with IDF ( $p=0,006$ and $p=0,016$, respectively). When the waist girth is introduced in NCEP-ATP III and NHLBI-AHA definitions as obligatory, this distinction was lost. The NCEP-ATP III and AHA/NHLBI definition is more suitable for discrimination of MetS diagnosis, than the later proposed IDF definition in the subjects of the given population. Inclusion of waist circumference as obligatory criteria failed to show increase in predictive accuracy for CAD.

Keywords: metabolic syndrome, central adiposity, coronary artery disease

\section{INTRODUCTION}

After a brief loss of interest in metabolic syndrome (MetS), apon the criticism made on account of it's diagnosis, the metabolic syndrome comes back into the spotlight, mainly because of its link with the global epidemics of cardiovascular diseases (CVD) and type 2 diabetes. This relationship was well established, but using different definitions proposed by several groups, brings confusion in clinical practice about which criteria should be used for the population of the given interest.

The most widely used is the National Cholesterol Education Program Adult Treatment Panel III (NCEP ATP III) definition [1]. In contrast to the definition of the World Health Organization (WHO) [2], it does not require the determination of insulin levels, thereby facilitating the assessment of MetS prevalence. The NCEP ATP III definition has been modified by the American Heart Association and the National Heart, Lung, and Blood Institute (AHA/NHLBI) $[3,4]$. The major adjustment was to in- clude persons reporting a history of current antihypertensive drug or lipid lowering medication use regardless of measured values.

Later proposed, the International Diabetes Federation (IDF) definition introduced [5] a central adiposity as a prerequisite to the diagnosis of the MetS. This definition, which was made with the intent to be globally applicable, also reduced the cutoff value for discriminating the central adiposity [6].

Consequently, we have multiple definitions for metabolic syndrome using in clinical practice now, some of which require central obesity as mandatory criterion for the diagnosis, and not others, while situation is even more complicated by the existence of different limits for discrimination of abdominal obesity.

There are only few studies related to the problem of different definitions showing their effect on the actual prevalence of the MetS in the given population [7-12], and even less emphasizing the unique role of central obesity in it [13-15]. 


\section{STUDY OBJECTIVE}

The aim of this study was [1] to assess the impact of the NCEP ATP III, AHA/NHLBI and IDF definitions on the overall prevalence rate of the MetS in high risk patients for coronary artery disease (CAD) recruited in a primary health care setting and outpatient clinical practice, [2] to determine the predictive power of these three different definitions of MetS for CAD, and [3] to establish the impact of abdominal obesity when it's introduced by different levels as a mandatory inclusion criteria for defining metabolic syndrome.

\section{MATHERIAL AND METHODS}

Study design and recruitment modalities: This was an observational cross-sectional study conducted during October 2008. in 3 university hospital centers in the north, midst and south of the Serbia. Physicians were recruited in different settings in clinical practice - office or hospital based cardiologists, endocrinologists / diabetologists and primary care physicians/internists - on the one third bases. Number of physicians recruited was proportional to the population size gravitating to the city outpatient clinics and primary health care offices. The every patient of a consultation day was invited to participate in the study whatever his/her condition or reason for consultation, with a target of 12 subjects to be recruited for each physician (maximum 20).

Inclusion and exclusion criteria: Patients were eligible if they were a male or female outpatient between 35 and 80 years of age and had signed an informed consent prior to any study procedures. Exclusion criteria were: subject currently hospitalized, any major surgery performed within the past 30 days, myocardial infarction or stroke within the past 30 days, pregnant or breast-feeding woman, presence of cirrhosis with ascites, known hyperthyroidism or hypothyroidism, current treatment with oral retinoïds (acne, psoriasis), systemic corticosteroids, antiretroviral or anti-obesity drugs (e.g., sibutramine, orlistat), CB1 blocker, actual or anticipated geographic or social factors that would prevent the subject from undergoing the fasting blood sample. Information on all criteria was collected using a questionnaire.

Sample size estimation: The sample size calculation was defined at country level and based on 95\% confidence interval to estimate the prevalence of MetS. With computed lower bound border of expected prevalence range $(20-70 \%)$ and a chosen precision of $2 \%$ the estimated number of patients was 1535 . Assuming a rate of up to $10 \%$ of subjects with missing data, a total number of 1690 patients were intended for enrollment.

Data Collected: All parameters required for diagnosis of MetS were assessed - anthropometric parameters and data on cardiovascular risk factors as well as data on therapy for hypertension, dyslipidemia and diabetes mellitus. Patient's assessment was carried out during a single visit to physician, with related fasting blood samples analysis completed up in seven days (to maximum three weeks) after the visit.

Anthropometric parameters: The body weight was assessed using a calibrated standard balance beam, height was measured by standard height bar, and the body mass index (BMl) was calculated as weight $(\mathrm{kg}) \mathrm{di}$ vided by height (m2) [16]. Waist circumference (WC) was measured at the midway between the lower rib and the iliac crest [16].

Blood pressure: Blood pressure measurements were taken using appropriately sized cuffs and the auscultator method recommended by the Seventh report of the Joint National Committee on prevention, Detection, Evaluation, and Treatment of High Blood Pressure [17].

Biochemical tests: For estimating the metabolic parameters, fasting blood glucose (FBG) and lipoproteins, blood samples were obtained after an overnight fast and abstention from liquids. The levels of FBG, total cholesterol (TC), serum triglycerides (TG), high-density lipoprotein cholesterol (HDL), and low-density lipoprotein cholesterol (LDL) were estimated using the commercial kits on an automated analyzer.

Smoking: Each participant was classified as a nonsmoker, former smoker, or current smoker, but for the purpose of the present study "ever smoker" status (current or former) was used.

Educational status: Educational status was assessed by terms of credentials earned. Each participant was classified as: elementary school, high school, college and university or without any education. In the present study division on lower and higher levels (college and university) of educational status was used.

Metabolic syndrome definitions: To evaluate the impact of different criteria and cutoff values for diagnosing the MetS, the prevalence was assessed using NCEP ATP III, AHA/NHLBI and IDF definitions. Since numerous studies using the NCEP ATP III definition included a history of current antihypertensive drug or lipid lowering medication use regardless of measured values, although explicitly not mentioned in the original definition (Table 1), we considered subjects using medication as having MetS (modified NCEP ATP III definition).

Statistical analysis: Data are expressed as mean values with standard deviations or as medians with interquartile ranges (for skewed data - not Gaussian distribution). The normal distribution of each variable was tested by Kolmogorov-Smirnov's test. Categorical data are presented by absolute numbers with percentages and 95\% confidence intervals, and analyzed using a chisquare test. For continuous variables, Student's t test or the Mann-Whitney U-test was used. To evaluate the impact of the 3 different definitions of MetS on CAD incidence, several logistic regression models were performed: univariate models where each model separately included only one of the 3 definitions of MetS as an independent predictor variable, and multivariate models, adjusted for age, gender, smoking and educational status. In all regressions, CAD was the dependent variable. The accuracy of the definitions in predicting CAD events was assessed by the means of the Receiver Operating Characteristic (ROC) curves, and their respective areas under the curve (AUC). A ROC curve is a graph of sensitivity versus 1 -specificity for various cut-off points of a positive diagnostic test result, herein the probability of CAD development was calculated by the models. Statistical analysis was performed using SPSS, version 17.0, software (SPSS Inc., Chicago, IL, USA). For comparison between ROC curves MedCalc statistical software has been used. p-value below 0.05 was considered statistically significant. 


\section{RESULTS}

1715 patients were included in the study $(63,1 \% \mathrm{fe}$ males, mean age: $58,5 \pm 9,8$ years), of whom $373(21,7 \%)$ sustained coronary artery disease, while for 48 patients $(2,8 \%)$ there are no data on the existence of coronary disease. The clinical, demographic and laboratory characteristics of the study population, according to the presence or not of CAD and to their classification using 3 different definitions of MetS are shown in Tables 2 and 3.

By applying the different definitions of MetS according to NCEP ATP III, NHLBI/AHA and IDF, its prevalence in the CAD group was $84,7 \%, 86,1 \%$ and $82,0 \%$, respectively, compared with $58,3 \%, 60,6 \%$ and $61,2 \%$ in the control group (statistically significant difference for all comparisons between the two groups, $p<0.0001$ ).

Univariate logistic regression models revealed that all 3 definitions of MetS were significantly associated with the presence of CAD $(p<0,0001)$, which are also shown with definitions where is waist circumference introduced as mandatory criteria for the diagnosis of metabolic syndrome (Table 4).

After adjusting for age, gender, smoking and educational status, all 3 definitions remain independently associated with the presence of CAD $(p<0,0001)$.

In order to distinct which definition model has a better predictive accuracy for CAD development, ROC curves were ploted and areas under the curve (AUC) with 95\% confidence intervals for AUC were estimated (Table $5)$.

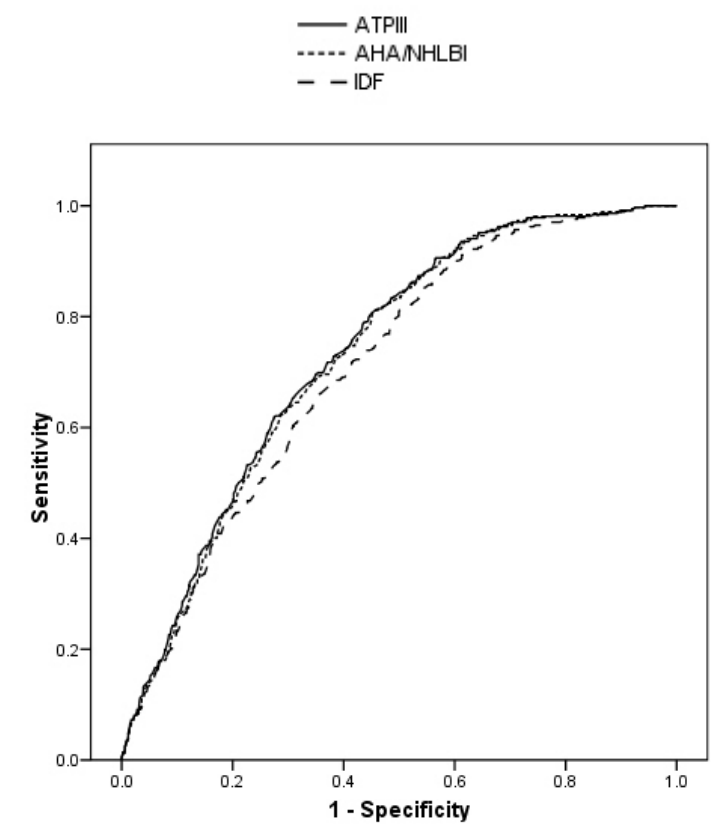

Figure 1. Plots of Receiver-Operating Characteristic (ROC) curves for the probabilities of the three multivariate models (each one containing a different definition of metabolic syndrome) used to predict coronary artery disease. (NCEP ATP, National Cholesterol Education Program Adult Treatment Panel; NHLBI/ AHA, National Heart, Lung and Blood Institute/ American Heart Association; IDF, International Diabetes Federation)

Table 1. NCEP ATP III, AHA/ NHLBI and IDF criteria for definition of metabolic syndrome

\begin{tabular}{|c|c|c|c|}
\hline Criterion & $\begin{array}{c}\text { NCEP ATP III } \\
\text { Three or more of the } \\
\text { following }\end{array}$ & $\begin{array}{c}\text { AHA/NHLBI } \\
\text { Three or more of the } \\
\text { following }\end{array}$ & $\begin{array}{l}\text { IDF } \\
\text { Waist circumference plus } \\
\text { any two of the following }\end{array}$ \\
\hline Systolic and/or diastolic BP & $\begin{array}{l}\geq 130 / 85 \mathrm{mmHg} \\
\text { or under therapy }\end{array}$ & $\begin{array}{l}\geq 130 / 85 \mathrm{mmHg} \\
\text { or under therapy }\end{array}$ & $\begin{array}{l}\geq 130 / 85 \mathrm{mmHg} \\
\text { or under therapy }\end{array}$ \\
\hline HDL cholesterol & $\begin{array}{l}<1,03 / 1,29 \mathrm{mmol} / \mathrm{L} \\
\text { or under therapy }\end{array}$ & $\begin{array}{l}<1,03 / 1,29 \mathrm{mmol} / \mathrm{L} \\
\text { or under therapy }\end{array}$ & $\begin{array}{l}<1,03 / 1,29 \mathrm{mmol} / \mathrm{L} \\
\text { or under therapy }\end{array}$ \\
\hline Triglycerides & $\begin{array}{l}\geq 1,7 \mathrm{mmol} / \mathrm{L} \\
\text { or under therapy }\end{array}$ & $\begin{array}{l}\geq 1,7 \mathrm{mmol} / \mathrm{L} \\
\text { or under therapy }\end{array}$ & $\begin{array}{l}\geq 1,7 \mathrm{mmol} / \mathrm{L} \\
\text { or under therapy }\end{array}$ \\
\hline Waist circumference $M / \bar{F}^{-}$ & $>102 / 88 \mathrm{~cm}$ & $>102 / 88 \mathrm{~cm}$ & $>94 / 80 \mathrm{~cm}$ \\
\hline Fasting plasma glucose & $\begin{array}{c}\geq 6,1 \mathrm{mmol} / \mathrm{L} \\
\text { or under therapy }\end{array}$ & $\begin{array}{l}\geq 5,6 \mathrm{mmol} / \mathrm{L} \\
\text { or under therapy }\end{array}$ & $\begin{array}{l}\geq 5,6 \mathrm{mmol} / \mathrm{L} \\
\text { or under therapy }\end{array}$ \\
\hline
\end{tabular}

BP - blood pressure

Table 2. Baseline clinical and laboratory characteristics in the study population, according to the presence of coronary artery disease (CAD)

\begin{tabular}{|c|c|c|c|}
\hline \multirow{2}{*}{ Variable } & \multicolumn{2}{|c|}{ Coronary artery disease (CAD) } & \multirow{2}{*}{$\mathbf{p}$} \\
\hline & CAD - $(n=1294)$ & $C A D+(n=373)$ & \\
\hline Age (years) & $57,3 \pm 9,9$ & $62,6 \pm 8,4$ & $<0,0001$ \\
\hline Gender (male), n (\%) & $439(33,9)$ & $177(47,5)$ & $<0,0001$ \\
\hline Smoking (former/current), $\mathrm{n}$ (\%) & $609(47,1)$ & $186(49,9)$ & 0,340 \\
\hline Educational status (higher level), n (\%) & $460(35,7)$ & $117(31,4)$ & 0,125 \\
\hline $\bar{B} \bar{M}\left(\mathrm{~kg} / \mathrm{m}^{2}\right)$ & $27,8(6,3)$ & $28,6(4,7)$ & $<0,0001$ \\
\hline Waist circumference in females $(\mathrm{cm})$ & $90,00(17)$ & $96,50(16)$ & $<0,0001$ \\
\hline Waist circumference in males $(\mathrm{cm})$ & $100,00(15)$ & $104,00(13)$ & $<0,0001$ \\
\hline $\mathrm{H} \overline{\mathrm{L}} \mathrm{L}$ cholesterol in females(mmol/L $)$ & $1,40(0,45)$ & $1,33(0,41)$ & $<0,0001$ \\
\hline HOL cholesterol in males (mmololl & $1,18(0,36)$ & $1,11(0,33)$ & $<0,0001$ \\
\hline Triglycerides (mmoli/L) & $1,59(1,06)$ & $1,73(1,21)$ & 0,002 \\
\hline Systolic BP (mmHg) & $136(30)$ & $140(25)$ & 0,022 \\
\hline Diastolic BP (mmHg) & $80(10)$ & $80(10)$ & 0,180 \\
\hline Ǵlucose (mmol/L) & $5,5(1,5)$ & $5,8(1,9)$ & $<0,0001$ \\
\hline
\end{tabular}

$\mathrm{BP}$ - blood pressure 
Table 3. Prevalence of each item of metabolic syndrome according to the 3 different definitions of MetS

\begin{tabular}{|c|c|c|c|}
\hline \multirow{2}{*}{ Variable } & \multicolumn{2}{|c|}{ Coronary artery disease (CAD) } & \multirow{2}{*}{ p } \\
\hline & CAD - $(n=1294)$ & $C A D+(n=373)$ & \\
\hline Systolic and/or diastolic BP increased or under therapy & $1090(84,2 ; 82,2-86,2)$ & $364(97,6 ; 96,0-99,0)$ & $<0,0001$ \\
\hline HDL cholesterol decreased or under therapy & $601(46,4 ; 43,7-49,2)$ & $268(71,8 ; 67,3-76,4)$ & $<0,0001$ \\
\hline Triglycerides increased or under therapy & $687(53,1 ; 50,4-55,8)$ & $289(77,5 ; 73,2-81,7)$ & $<0,0001$ \\
\hline Waist circumference increased ATP III/NHLB -AHA & $734(56,7 ; 54,0-59,4)$ & $255(68,4 ; 63,6-73,1)$ & $<0,0001$ \\
\hline Waist circumference increased IDF & $1050(81,1 ; 79,0-83,3)$ & $328(87,9 ; 84,6-91,2)$ & $<0,0001$ \\
\hline Glucose increased or under therapy ATP IIII & $516(39,9 ; 37,2-42,5)$ & $199(53,4 ; 48,3-58,4)$ & $<0,0001$ \\
\hline Glucose increased or under therapy NHLBI-AHA/IDF & $636(49,1 ; 46,4-51,9)$ & $229(61,4 ; 56,4-66,3)$ & $<0,0001$ \\
\hline MetS, NCEP-ATTP III & $754(58,3 ; 55,6-61,0)$ & $316(84,7 ; 81,1-88,4)$ & $<0,0001$ \\
\hline MetS, NHLBI-AHA & $784(60,6 ; 57,9-63,7)$ & $321(86,1 ; 82,5-90,0)$ & $<0,0001$ \\
\hline Mets, İ & $792(61,2 ; 58,6-63,4)$ & $306(82,0 ; 78,1-86,0)$ & $<0,0001$ \\
\hline
\end{tabular}

Data are presented as n (\%; $95 \% \mathrm{Cl})$

Table 4. Logistic regression analysis models for presence of coronary artery disease in relation to the MetS defined by different definitions

\begin{tabular}{|c|c|c|c|c|c|}
\hline Presence of MetS according to & OR & $95 \% \mathrm{Cl}$ for $\mathrm{OR}$ & OR adjusted & $\begin{array}{c}95 \% \mathrm{Cl} \\
\text { for OR adjusted }\end{array}$ & P \\
\hline NCEP-ATP III & 3,970 & $2,933-5,375$ & 4,084 & $2,971-5,615$ & $<0,0001^{\#}$ \\
\hline N̄HL̄BI-ĀHA & 4,016 & $2,935-5,494$ & 3,956 & $2,854-5,482$ & $<0,0001^{\#}$ \\
\hline İDF $\bar{F}^{-\cdots+\cdots}$ & 2,650 & $2,002-3,507$ & 2,652 & $1,967-3,576$ & $<0,0001^{\#}$ \\
\hline NCEP-ATP III with mandatory WC & 2,403 & $1,892-3,051$ & 2,559 & $1,985-3,299$ & $<0,0001^{\#}$ \\
\hline NHLBI-ĀHA with mandatory WC & 2,336 & $1,838-2,969$ & 2,403 & $1,863-3,098$ & $<0,0001^{\#}$ \\
\hline
\end{tabular}

${ }^{\#} \mathrm{p}$ value is for both unadjusted and adjusted models; adjustment were done for age, gender, smoking and educational status; WC - waist circumference

Table 5. Areas under the Receiver Operating Characteristic (ROC) curve for various models (each one containing different definition of MetS) for presence of coronary artery disease

\begin{tabular}{|c|c|c|c|c|c|}
\hline Presence of MetS according to & AUC & $95 \% \mathrm{Cl}$ for $\mathrm{AUC}$ & AUC adjusted & $\begin{array}{c}95 \% \mathrm{Cl} \text { for } \\
\text { AUC adjusted }\end{array}$ & $\mathbf{p}$ \\
\hline NCEP-ATP III & 0,638 & $0,614-0,661$ & 0,736 & $0,714-0,757$ & $<0,0001^{\#}$ \\
\hline NHLBI-AHA & 0,627 & $0,604-0,651$ & $0,730^{-}$ & $0,708-0,752$ & $<0,0001^{-1}$ \\
\hline IDFF & 0,597 & $0,573-0,621$ & 0,709 & $0,686-0,731$ & $<0,0001^{\#-}$ \\
\hline NCEP-ATTP III with mandatory WC & 0,607 & $0,575-0,639$ & 0,717 & $0,695-0,739$ & $<0,0001^{-1}$ \\
\hline NHLBI-ĀHA with mandatory WC & $0,603^{-}$ & $0,571-0,635$ & $0,714^{-}$ & $0,691-0,735$ & $<0,0001^{-1}$ \\
\hline
\end{tabular}

\# $p$ value is for both unadjusted and adjusted models; adjustment were done for age, gender, smoking and educational status

Probabilities of CAD development calculated by the previous (unadjusted and adjusted) logistic regression models were used to plot the ROC curves and to estimate the AUCs. The use of NCEP-ATP III and NHLBI-AHA definitions indicated better predictive accuracy compared with the definition model containing IDF: there is no statistical significance between ROC curves for NCEP-ATP III and NHLBI-AHA definitions $(p=0,156)$, while there is significance between IDF definition and these two: $p=0,006$ (difference between areas 0,$027 ; 95 \% \mathrm{Cl}$ for difference $0,008-0,046$ ) and $\mathrm{p}=0,016$ (difference between areas 0,$022 ; 95 \% \mathrm{Cl}$ for difference $0,004-0,039$ ), respectively. When the weight girth is introduced in NCEP-ATP III and NHLBI-AHA definitions as obligatory, this distinction between definitions is lost $(p=0,163 ; p=0,585$ and $p=0,344$ respectively). The AUCs of the ROC analyses for 3 official definitions (NCEP-ATP III, NHLBI-AHA and IDF) based on the multivariate models are shown in Fig. 1.

\section{DISCUSSION}

In this observational study we assessed the predictive power of three different definitions (ATP III,
NHLBI/AHA and IDF) of MetS in high risk patients for CAD recruited in a primary health care setting and outpatient clinical practice. Also, we assessed the impact of the introduction of waist girth as mandatory criterion in the definitions of MetS. Our findings are consistent with previous reports indicating that all 3 definitions are predictive of CAD $[11,12,18,19]$, but also that all three definitions give a different prevalence of MetS.

Recent studies indicated that the definition proposed by IDF may have higher accuracy in identifying individuals at very high cardiovascular risk compared with NCEP-ATP III and NHLBI definitions [20-22]. The IDF definition emphasizes WC, an established index of abdominal obesity [23] which provides information not only for conventional risk factors [24], but is oriented more towards cardiometabolic risk [25]. Therefore, the assumption is that it would be more likely to have stronger discriminative power than the current definitions in identifying future CAD events.

In our study, implementation of IDF criteria did not result in an increased predictive power of MetS for CAD compared with other definitions. This can be explained primarily with too strict criteria for WC in the IDF definition, which in turn, when being a mandatory criterion for diagnosing MetS at lower cut-off in ATP III and 
NHLBI/AHA definitions, hasn't reinforced their predictive power, neither.

After performing multivariate analyses, adjusted for age, gender, smoking and educational status, results of the analysis remained unchanged.

There are discrepancies among studies investigating the accuracy of various MetS definitions in CAD prediction, that could be attributed to the use of different populations (general population or population under risk) and different endpoints (CAD vs. CVD events), making the results not entirely comparable. On the other hand, major changes in definitions like the inclusion of pharmacotherapy as criteria for hypertension, diabetes or dislipydemia, i.e. [10,26-29] further hamper the interpretation of different study results. Pharmacotherapy is not mentioned in the original NCEP ATP III and AHA/NHLBI definitions and explicitly not included until the 2005 AHA/NHLBI update [4]. Besides, most of the studies included hypertensive medications, but not lipid lowering drugs. It remains an open point of discussion, if this would create a selection bias leading to an under- or overestimation of the true prevalence of MetS. In this study, subjects who were under any medical therapy were defined as meeting MetS criteria when using the NCEP ATP-III and NHLBI/AHA definitions, while IDF included this in its original definition.

In this study, the examined population was patients recruited in cardiology and endocrinology outpatient clinics and primary health care physicians' offices/internists', with the intention to compare the three most used MetS definitions as predictive tools for CAD events in the subjects who were at high risk for CAD in routine clinical practice. Also it was intended to show whether the introduction of WC as a mandatory criterion in the MetS definition increases its value for discrimination of the patients with increased risk of coronary disease. Therefore, the prevalence of MetS and increased WC was found to be high in the subjects of the given population and cannot be extrapolated to the general population.

\section{CONCLUSION}

In conclusion, the definition of MetS according to NCEP-ATP III and NHLBI/AHA criteria were found to be significantly better predictors of CAD than the IDF one, after adjustment for confounders. Although it was expected that inclusion of WC as an obligatory criterion would add more prognostic information beyond MetS official definitions, this analysis failed to show increase in predictive accuracy for CAD.

The findings of our study should be interpreted with the caution of the limitations that brings cross-sectional design, so the longitudinal study will be conducted to prove that subjects with MetS are really more prone to develop atherosclerotic cardiovascular disease, even though some recently published studies (30) concluded that MetS is not a sensible tool for predicting the risk of CAD.

\section{REFERENCES}

1. Executive Summary of The Third Report of The National Cholesterol Education Program (NCEP) Expert Panel on Detection, Evaluation, And Treatment of High Blood Cholesterol In Adults (Adult Treatment Panel III). JAMA 2001;285:2486-2497.

2. Alberti KG, Zimmet PZ. Definition, diagnosis and classification of diabetes mellitus and its complications. Part 1: diagnosis and classification of diabetes mellitus provisional report of a WHO consultation. Diabet Med 1998;15:539-553.

3. Grundy SM, Brewer HB, Cleeman JI, Smith SC, Lenfant C. Definition of metabolic syndrome: Report of the National Heart, Lung, and Blood Institute/American Heart Association. Circulation 2004;109:433-438.

4. Grundy SM, Cleeman JI, Daniels SR, Donato KA, Eckel RH, Franklin BA, Gordon DJ, Krauss RM, Savage PJ, Smith SC, Jr., Spertus JA, Costa F. Diagnosis and Management of the Metabolic Syndrome: An American Heart Association/National Heart, Lung, and Blood Institute Scientific Statement. Circulation 2005;112:2735-2752.

5. Federation ID. The IDF consensus worldwide definition of the metabolic syndrom. International Diabetes Federation www.idf.org; 2005. pp. 1-14.

6. Alberti KG, Zimmet P. Shaw J; IDF Epidemiology Task Force Consensus Group. The metabolic syndrome - a new worldwide definition. Lancet 2005;366:1059-1062.

7. Nilsson PM, Engstrom G, Hedblad B. The metabolic syndrome and incidence of cardiovascular disease in non-diabetic subjects a population-based study comparing three different definitions. Diabet Med 2007;24:464-472. 
8. Saely CH, Koch L, Schmid F, Marte T, Aczel S, Langer P, Hoefle G, Drexel H. Adult Treatment Panel III 2001 but not International Diabetes Federation 2005 criteria of the metabolic syndrome predict clinical cardiovascular events in subjects who underwent coronary angiography. Diabetes Care 2006;29:901-907.

9. Tong PC, Kong AP, So WY, Yang X, Ho CS, Ma RC, Ozaki R, Chow CC, Lam CW, Chan JC, Cockram CS. The usefulness of the International Diabetes Federation and the National Cholesterol Education Program's Adult Treatment Panel III definitions of the metabolic syndrome in predicting coronary heart disease in subjects with type 2 diabetes. Diabetes Care 2007;30(5):1206-1211.

10. Lawlor DA, Smith GD, Ebrahim S. Does the new International Diabetes Federation definition of the metabolic syndrome predict CHD any more strongly than older definitions? Findings from the British Women's Heart and Health Study. Diabetologia 2006;49: 41-48.

11. Qiao Q. Comparison of different definitions of the metabolic syndrome in relation to cardiovascular mortality in European men and women. Diabetologia 2006;49:2837-2846.

12. Sattar N, Gaw A, Scherbakova O, Ford I, O'Reilly DS, Haffner SM, Isles C,Macfarlane PW, Packard CJ, Cobbe SM, Shepherd J. Metabolic syndrome with and without C-reactive protein as a predictor of coronary heart disease and diabetes in the West of Scotland Coronary Prevention Study. Circulation 2003;108:414-419.

13. Koutsovasilis A, Protopsaltis J, Triposkiadis F, Kokkoris S, Milionis HJ,Zairis MN, Skoularigis J, Koukoulis G, Korantzopoulos P, Melidonis A, Foussas SG. Comparative Performance of Three Metabolic Syndrome Definitions in the Prediction of Acute Coronary Syndrome. Inter Med 2009;48:179-187.

14. Katzmarzyk PT, Janssen I, Ross R, Church TS, Blair SN. The importance of waist circumference in the definition of metabolic syndrome: prospective analyses of mortality in men. Diabetes Care 2006;29:404-409.

15. Parapid B, Ostojic MC, Lalic NM, Micic D, Damjanovic S, Bubanja D, Simic D, Lalic K, Polovina S, Marinkovic J, Milic NM. Risk factors clustering within the metabolic syndrome: a pattern or by chance? Hellenic J Cardiol. 2014;55(2):92-100.

16. World Health Organization. Obesity: Preventing and Managin the Global epidemic. Geneva: WHO; 1998.

17. Chobanian AV, Bakris GL, Black HR, Cushman WC, Green LA, Izzo JL Jr, Jones DW, Materson BJ, Oparil S, Wright JT Jr, Roccella EJ; National Heart, Lung, and Bloodlnstitute Joint National Committee on Prevention, Detection, Evaluation, andTreatment of High Blood Pressure; National High Blood Pressure Education Program Coordinating Committee. The Seventh Report of the Joint National Committee onPrevention, Detection, Evaluation, and Treatment of High Blood Pressure: the JNC 7 report. JAMA 2003;289(19):2560-2572.

18. Hwang YC, Jee JH, Oh EY, Choi YH, Lee MS, Kim KW, Lee MK. Metabolic syndrome as a predictor of cardiovascular diseases and type 2 diabetes in Koreans. Int J Cardiol 2009;134(3):313-321.

19. Wang C, Hou X, Bao Y, Pan J, Zuo Y, Zhong W, Jia W, Xiang K. The metabolic syndrome increased risk of cardiovascular events in Chinese-A community based study. Int J Cardiol 2008 Nov 27. [Epub ahead of print]

20. Kuusisto J, Mykkanen L, Pyorala K, Laakso M. Hyperinsulinemic microalbuminuria. A new risk indicator for coronary heart disease. Circulation 1995;91:831-837.

21. Willerson JT, Ridker PM. Inflammation as a cardiovascular risk factor. Circulation 2004;109:I12-10.

22. Lorenzo C, Williams K, Hunt KJ, Haffner SM. The National Cholesterol Education Program Adult Treatment Panel III, International Diabetes Federation, and World Health Organization definitions of the metabolic syndrome as predictors of incident cardiovascular disease and diabetes. Diabetes Care 2007;30: 8-13.

23. Balkau B, Deanfield JE, Després JP, Bassan JP, Fox KAA, Smith SC. International Day for the Evaluation of Abdominal Obesity (IDEA): a study of waist circumference, cardiovascular disease, and diabetes mellitus in 168000 primary care patients in 63 countries. Circulation 2007;116(17):1942-1951.

24. Yusuf S, Hawken S, Ounpuu S, Bautista L, Franzosi MG, Commerford P, Lang CC, Rumboldt Z, Onen CL, Lisheng L, Tanomsup S, Wangai P Jr, Razak F, Sharma AM, Anand SS; INTERHEART Study Investigators. Obesity and the risk of myocardial infarction in 27,000 participants from 52 countries: a case-control study. Lancet 2005;366(9497:1640-1649.

25. Cote $\mathrm{M}$, Mauriege $\mathrm{P}$, Bergeron J, et al. Adiponectinemia in visceral obesity: impact on glucose tolerance and plasma lipoprotein and lipid levels in men. J Clin Endocrinol Metab 2005;90: 1434-1439.

26. Ford ES. Prevalence of the Metabolic Syndrome Defined by the International Diabetes Federation Among Adults in the U.S. Diabetes Care 2005;28:2745-2749.

27. Lorenzo C, Serrano-Rios M, Martinez-Larrad MT, Gabriel R, Williams K, Gomez-Gerique JA, Stern MP, Haffner SM. Central adiposity determines prevalence differences of the metabolic syndrome. Obes Res 2003;11:1480-1487.

28. Sundstrom J, Riserus U, Byberg L, Zethelius B, Lithell H, Lind L. Clinical value of the metabolic syndrome for long term prediction of total and cardiovascular mortality: prospective, population based cohort study. BMJ 2006;332:878-882.

29. Gu D, Reynolds K, Wu X, Chen J, Duan X, Reynolds RF, Whelton PK, He J, Group IASIAC. Prevalence of the metabolic syndrome and overweight among adults in China. Lancet 2005;365:1398-1405.

30. Woodward $\mathrm{M}$, Tunstall-Pedoe $\mathrm{H}$. The metabolic syndrome is not a sensible tool for predicting the risk of coronary heart disease. Eur J Cardiovasc Prev Rehabil 2009;16(2):210-214. 


\section{SRPSKI}

\section{KOMPARACIJA RAZLIČITIH DEFINICIJA METABOLIČKOG SINDROMA U RELACIJI SA BOLEŠĆU KORONARNIH ARTERIJA U VISOKO RIZIČNOJ POPULACIJI SRBIJE}

Veličković I. ${ }^{1}$, Milin-Lazović J. ${ }^{2}$, Nestorović E. ${ }^{3}$, Ćirković A. ${ }^{2}$, Savić M. ${ }^{3}$, Stojković N. ${ }^{1}$, Mašić S. ${ }^{4}$, Milić N. ${ }^{2}$

${ }^{1}$ Visoka medicinska škola strukovnih studija, Zemun, Srbija

${ }^{2}$ Institut za medicinsku statistiku i informatiku, Medicinski fakultet Univerziteta u Beogradu, Srbija

${ }^{3}$ Klinički centar Srbije

${ }^{4}$ Medicinski fakultet Univerzitet u Istočnom Sarajevu, Bosna i Hercegovina

\section{SAŽETAK}

Postoje razlicite definicije metabolickog sindroma (MetS), ali su potrebni precizni kriterijumi za njihovu primenu u klinickoj praksi. Primenili smo observacionu studiju poprecnog preseka, sprovedenu tokom oktobra 2008.godine, u 3 univerzitetska bolnicka centra, u severnom, cetralnom I juznom regionu Srbije. Ispitano je 1715 pacijenata na ambulantnom lecenju I lecenih u primarnoj zdravstvenoj zastiti, od cega $37 \%$ muskaraca I $63 \%$ zena, starosne dobi od $34-80$ godina. U cilju evaluacije uticaja razlicitih kriterijuma na utvrdjivanje populacije sa visokim rizikom za koronarne bolesti (KVB), koristili smo NCEP-ATP III, AHA/NHLBI I IDF definicije. Kod 27.7\% (373) pacijenata ukljucenih u studiju je perzistirala koronarna bolest. Prevalenca metabolickog sindroma u grupi sa koronarnom bolescu je bila $84.7 \%, 86.1 \%$ I 82.0\% sledstveno, u poredjenju sa $58.3 \%$, 60.6\% I $61.2 \%$ u kontrolnoj grupi $(p<0.0001)$. ROC kriva vrovatnoće izračunata na osnovu logističke regresije za svaku od definicija za kardiovaskularne bolesti koje smo racunali smo logickim modelom za svaku definiciju (uzimajuci u obzir starost, pol, pusenje i stepen obrazovanja) je pokazala da su NCEP-ATP III I NHLBI-AHA definicije imale vecu prediktivnu preciznost u poredjenju sa IDF ( $p=0,006$ and $p=0,016$, sledstveno). Uvodjenjem obima struka u NCEP-ATR III i NHLBI AHA definiciju kao obaveznu, ova razlika se gubi. NCEP-ATP III i AHA/NHLBI definicija je primenljivija za diskriminacionu analizu dijagnoze metabolickog sindroma, od kasnije predlozene IDF definicije kod ispitanika odredjene populacione grupe. Ukljucivanje obima struka, kao obaveznog kriterijuma nije pokazalo povecanje prediktivne preciznosti za koronarnu bolest.

Ključne reči: metabolički sindrom, centralna gojaznost, bolest koronarnih arterija 